\title{
Does the beneficial effect of mycophenolate mofetil persist long-term in the treatment of non-infectious uveitis?
}

\section{Czy korzystny efekt mykofenolanu mofetilu w leczeniu nieinfekcyjnych zapaleń błony naczyniowej utrzymuje się długoterminowo?}

\author{
Maja Waszczyk-tączak', Jacek P. Szaflik ${ }^{1,2}$ \\ Independent Public University Ophthalmic Hospital of Warsaw, Poland \\ Head: Professor Jacek P. Szaflik, MD, PhD \\ 2 Department of Ophthalmology, 2nd Faculty of Medicine, the Medical University of Warsaw, Poland \\ Head: Professor Jacek P. Szaflik, MD, PhD
}

\begin{abstract}
Ahstract: $\quad$ Aim: The aim of the study involved the assessment of long-term effectiveness of mycophenolate mofetil treatment in patients with chronic non-infectious uveitis.

Material and Methods: A retrospective analysis included case histories of 19 patients receiving mycophenolate mofetil with a follow-up period of at least 36 months. We assessed the possibility of reducing the dose of prednisolone to a dose equal to or lower than $10 \mathrm{mg}$ daily and achieving a remission after mycophenolate mofetil discontinuation. Moreover, the change in the best corrected visual acuity was evaluated at baseline and at the end of the follow-up.

Results: Nineteen patients were included in the study. The majority of them were women (18/19; 95\%). The average age when immunosuppressive therapy was introduced was 44 years (ranging from 21 to 75 years). The therapeutic success of glucocorticosteroid reduction, defined as the absence of symptoms of inflammation at the dose of prednisolone equal to or lower than $10 \mathrm{mg}$ per day, recorded during at least two follow-up visits planned 28 days apart after one year of therapy was obtained in 13 out of 16 patients (81\%), and after two years - in 14 out of 16 patients (87\%). After the completion of the therapy the recurrence was noted in 7 patients on average after a year. The total of 20 out of 31 eyes (64\%) achieved vision stabilization, an improvement occurred in eight eyes $(26 \%)$ and deterioration in three $(10 \%)$.

Conclusions: Data obtained from this study confirm the long-term effectiveness of mycophenolate mofetil in the treatment of non-infectious uveitis.

Key words: $\quad$ mycophenolate mofetil, non-infectious uveitis, immunosuppressive treatment

Ahstrakt: $\quad$ Cel: ocena długoterminowego efektu leczenia mykofenolanem mofetilu pacjentów z przewlekłym nieinfekcyjnym zapaleniem błony naczyniowej.

Materiał i metody: dokonano retrospektywnej analizy historii chorób 19 pacjentów otrzymujących mykofenolan mofetilu, u których okres obserwacji wynosił przynajmniej 36 miesięcy. Oceniano możliwość zredukowania dawki prednizolonu do dawki równej $10 \mathrm{mg}$ bądź mniejszej dziennie, a także uzyskanie remisji po odstawieniu mykofenolanu mofetilu. Analizowano również zmianę najlepszej skorygowanej ostrości wzroku na początku leczenia i na końcu obserwacji.

Wyniki: do badania włączono 19 pacjentów. Większość z nich stanowiły kobiety, aż 18 (95\%). Średnia wieku podczas włączania terapii immunosupresyjnej to 44 lata (zakres od 21 do 75 lat). Sukces terapeutyczny redukcji glikokortykosteroidów określono jako brak objawów zapalenia w warunkach stosowania dawki prednizolonu równej 10 mg bądź mniejszej dziennie, odnotowany na przynajmniej dwóch wizytach kontrolnych oddzielonych 28 dniami przerwy, po roku terapii uzyskano go u 13 spośród 16 pacjentów (81\%), po dwóch latach terapii - u 14 spośród 16 pacjentów (87\%). Po zakończeniu terapii u 7 osób zaobserwowano ponowne wystąpienie choroby - średnio po roku. W 20 oczach (64\%) spośród 31 oczu uzyskano stabilizację widzenia, poprawa wystąpita w 8 oczach (26\%), a pogorszenie w 3 oczach (10\%).

Wnioski: uzyskane dane potwierdzają długotrwałą skuteczność mykofenolanu mofetilu w leczeniu nieinfekcyjnego zapalenia błony naczyniowej.

Stowa kluczowe: mykofenolan mofetilu, nieinfekcyjne zapalenie błony naczyniowej, leczenie immunosupresyjne

Autorzy zgłaszają brak konfliktu interesów w związu $z$ publikowaną pracą/ The authors declare no conflict of interest
\end{abstract}

\section{Introduction}

Non-infectious uveitis refers to a group of pathologies characterized by various etiologies which are frequently difficult to determine explicitly. Local and systemic glucocorticosteroids (GC) are still the basic treatment. However, due to their ineffectiveness in some patients immunosuppressive drugs need to 
be introduced. In 2000 the American Journal of Ophthalmology published guidelines referring to the cases in which such a treatment should be considered (1):

- lack of local status improvement following a monthly treatment with glucocorticosteroids (at a dose equivalent to $60 \mathrm{mg}$ of prednisone daily),

- lack of inflammation remission following a long-term treatment with glucocorticosteroids at a dose equivalent to $10 \mathrm{mg}$ of prednisone daily,

- the occurrence of adverse effects during glucocorticosteroid therapy necessitating the discontinuation or marked dose reduction,

- in case of poor response to glucocorticosteroid therapy in a given condition.

The classification of immunosuppressive drugs is based on various mechanisms of action. Four main groups may be distinguished: antimetabolites, T-lymphocyte inhibitors, alkylating agents and biological drugs. Mycophenolate mofetil (MMF), together with azathioprine and methotrexate belong to the group of antimetabolites. MMF is a selective, reversible and noncompetitive inhibitor of inosine monophosphate dehydrogenase (IMPDH). This enzyme takes part in the synthesis of guanine nucleotides. DNA synthesis block, GTP pool depletion and protein glycosylation impairment are the direct consequences of inhibiting its activity.

A high effectiveness of MMF in the treatment of non-infectious uveitis is well-documented $(2,3,4,5,6)$. However, the majority of authors limited the follow-up period to 12 months in patients undergoing the treatment. Few authors published data obtained from long-term assessment of the effectiveness of this antimetabolite.

The aim of the study involved the assessment of long-term effectiveness of mycophenolate mofetil treatment in patients with chronic non-infectious uveitis. The follow-up period of at least 36 months was an inclusion criterion in this study.

\section{Material and Methods}

A retrospective analysis of data included in 31 case histories was conducted. The study group patients were treated with mycophenolate mofetil for non-infectious uveitis at the clinic of Independent Public University Ophthalmic Hospital in Warsaw. 19 patients with a follow-up period of at least 36 months were qualified for the study.

Patients qualified for immunosuppressive treatment were recruited from a group of the most severe cases. They usually had had a history of several years of the disease with several recurrences of the inflammation. When MMF was introduced into the treatment most of the patients were receiving GCs. The criteria for inclusion were as follows: a diagnosis of chronic non-infectious uveitis, mycophenolate mofetil treatment and 36 months of documented follow-up. The exclusion criteria were the inflammation of eye tissue other than uveitis and a shorter follow-up period.

The regimen of mycophenolate mofetil treatment was determined individually for each patient. The dose depended on the type of uveitis and the general health of the patient comprising the body weight and concomitant systemic diseases. Initially, the majority of patients received $1000 \mathrm{mg}$ of MMF twice a day and GCs. At first we aimed at the reduction of GC dose combined with a gradual reduction of MMF dose. Subsequently, MMF discontinuation was planned. If uveitis recurred during the pro- cess of dose reduction, the dose of the immunosuppressive drug was increased again. Since immunosuppressive therapy may activate viral infections (e.g. herpes simplex virus, cytomegalovirus, human papillomavirus) and induce atypical infections (Pneumocystis jirovecii), prophylaxis for 6 months with acyclovir ( $4 \times 400 \mathrm{mg}$ daily) and co-trimazole ( $480 \mathrm{mg}$ twice daily for 3 months tapered to $480 \mathrm{mg}$ daily) was introduced.

During the treatment we aimed at achieving the remission of uveitis manifestations while introducing the maximum reduction of GC dose (equal to or lower than $10 \mathrm{mg}$ of prednisolone) and a complete MMF discontinuation. According to SUN Working Group guidelines the therapeutic success of GCs dose reduction was defined as the lack of inflammation manifestations at a dose of prednisolone equal to or lower than $10 \mathrm{mg}$ daily (or an equivalent dose of methylprednisolone). The remission of inflammation after GC dose reduction had to be reported during at least two follow-up visits 28 days apart.

The remission was also determined using those guidelines according to which 3 asymptomatic months following MMF discontinuation was viewed as achieving therapeutic success (7).

At baseline all the patients underwent a complete ophthalmological examination including best corrected visual acuity (BCVA), tonometry, the assessment of the anterior and posterior segment of the eye with the slit lamp. The classification of uveitis was performed on the basis of guidelines of the Standardization of Uveitis Nomenclature (SUN) Working Group (7). The following information concerning the patients qualified for the study was obtained from their medical histories: demographic data, information about the duration of the disease and the number of recurrences prior to MMF introduction, previous immunosuppressive therapy, the reason for MMF introduction, drug dosages, disease complications, the frequency of surgical procedures, treatment duration, follow-up durations and the occurrence of inflammatory relapses during those periods, achieving the effectiveness of glucocorticosteroid dose reduction, successful remission obtained after MMF discontinuation, reason for MMF discontinuation, the occurrence of adverse effects and BCVA. The frequency of follow-up visits depended on the local status and the stage of treatment of a patient.

The aim of the study involved the assessment of the effectiveness of mycophenolate mofetil treatment in patients with chronic non-infectious uveitis. The effectiveness was assessed at several levels. Firstly, it concerned the possibility of reducing GCs dose to a pre-specified level. Secondly, it analysed the fact of achieving remission after MMF discontinuation. Thirdly, we evaluated the treatment basing on the comparison between baseline and final BCVA.

Visual acuity was assessed during each follow-up visit with the Snellen chart. The values obtained during examination were changed in accordance with appropriate rules into logMAR units with the lowest: counting fingers in front of the patient's eye - 1.9; hand motion in front of the patient's eye -2.3 ; light perception - 2.7; no light perception - 3.0. Improvement or deterioration in visual acuity was reported with a change of at least $0.3 \log$ MAR which translates into three rows on the Snellen chart.

Follow-up visits involved taking a history concerning possible adverse effects of the therapy and the assessment of basic laboratory tests. The small size of the study group was the re- 
ason why statistical formulas could not be used. Therefore, the calculations were executed with Excel spreadsheet.

The retrospective study was approved by the Bioethics Board of the Medical University of Warsaw.

\section{Results}

19 patients were included in the study. The majority of them were women (18/19; 95\%). The average age when immunosuppressive therapy was introduced was 44 years (ranging from 21 to 75 years). Table I includes patient characteristics.

Patients qualified for immunosuppressive treatment were recruited from a group of the most severe cases. Over half of the patients had had at least 6 inflammatory episodes prior to MMF introduction and the average duration of the disease was 10 years.
The average duration of follow-up after MMF therapy initiation was 51 months, the longest one was 106 months with a minimum of 36 months being an inclusion criterion. One patient was also continued on cyclosporine for the first 10 months of mycophenolate mofetil treatment.

The therapeutic success was defined as the absence of symptoms of inflammation at the dose of prednisolone of $\leq 10 \mathrm{mg}$ per day, recorded during at least two follow-up visits planned 28 days apart. Three patients did not receive GCs during MMF treatment. A yearly therapy proved successful in 13 out of 16 patients (81\%), and two years of therapy - in 14 out of 16 patients (87\%). Detailed data concerning GC dose reduction are included in Figure 1. Notably, some patients had the dose reduced to $10 \mathrm{mg}$ during the first year, and then $\mathrm{GC}$

\begin{tabular}{|c|c|c|c|}
\hline $\begin{array}{l}\text { Patients characteristics/ } \\
\text { Charakterystyka pacjentów }\end{array}$ & & $\mathbf{n}$ & $\%$ \\
\hline Mean age/ Średnia wieku [years/lata] & & $44.3(21-75)$ & \\
\hline$\%$ female/ \% kobiet & & 18 & $95 \%$ \\
\hline Unilateral uveitis $(\mathrm{R} / \mathrm{L}) /$ Choroba jednooczna $(\mathrm{P} / \mathrm{L})$ & & $7(2 / 5)$ & $37 \%(11 / 26)$ \\
\hline Bilateral uveitis/ Choroba obuoczna & & 12 & $63 \%$ \\
\hline \multicolumn{4}{|l|}{ Uveitis type/ Typ zapalenia } \\
\hline & Anterior uvritis/ Zapalenie przedniego odcinka błony naczyniowej & 6 & $32 \%$ \\
\hline & Intermediate uveitis/ Zapalenie części pośredniej błony naczyniowej & 3 & $16 \%$ \\
\hline & Posterior uveitis/ Zapalenie tylnego odcinka błony naczyniowej & 4 & $21 \%$ \\
\hline & Panuveitis / Zapalenie całej błony naczyniowej & 6 & $32 \%$ \\
\hline \multicolumn{2}{|c|}{ Mean durationof uveitis before MMF/ Średni czas trwania choroby przed włączeniem MMF [lata] } & 10.3 & \\
\hline & $\min$ [years] & 0.1 & \\
\hline & $\max$ [years] & 31 & \\
\hline \multicolumn{4}{|c|}{ Number of episodes before MMF/ Liczba epizodów przed włączeniem immunosupresji } \\
\hline & Less than 5 episodes/ Poniżej 5 epizodów & 8 & $42 \%$ \\
\hline & 6-10 episodes/ Od 6 do 10 epizodów & 2 & $10 \%$ \\
\hline & More than 10 episodes/ Powyżej 10 epizodów & 9 & $48 \%$ \\
\hline \multicolumn{2}{|c|}{ Previous immunosuppresive treatment/ Wcześniejsze leczenie immunosupresyjne } & 7 & $37 \%$ \\
\hline & Azathiopryne & 5 & $72 \%$ \\
\hline & Cyclosporyne A & 1 & $14 \%$ \\
\hline & Methotrexate & 1 & $14 \%$ \\
\hline \multicolumn{4}{|c|}{ Reason for starting MMF treatment/ Powód włączenia MMF } \\
\hline & $\begin{array}{l}\text { Inefficacy of corticosteroid therapy/ } \\
\text { Niepowodzenie terapii samymi steroidami }\end{array}$ & 8 & \\
\hline & Dependence on steroids/Steroidozależność & 2 & \\
\hline & $\begin{array}{l}\text { Inefficacy of previous immunosuppresive therapy/ } \\
\text { Brak skuteczności innych leków immunosupresyjnych }\end{array}$ & 5 & \\
\hline & Other reason/ Inny powód & 4 & \\
\hline
\end{tabular}

Tab. I. Patient characteristics, uveitis and treatment.

Tab. I. Charakterystyka pacjentów, choroby i leczenia. 
dose was further reduced to $5 \mathrm{mg}$ and even discontinued. At the beginning of MMF treatment 13 patients received prednisone at a dose higher than $10 \mathrm{mg}$ daily (68\%).

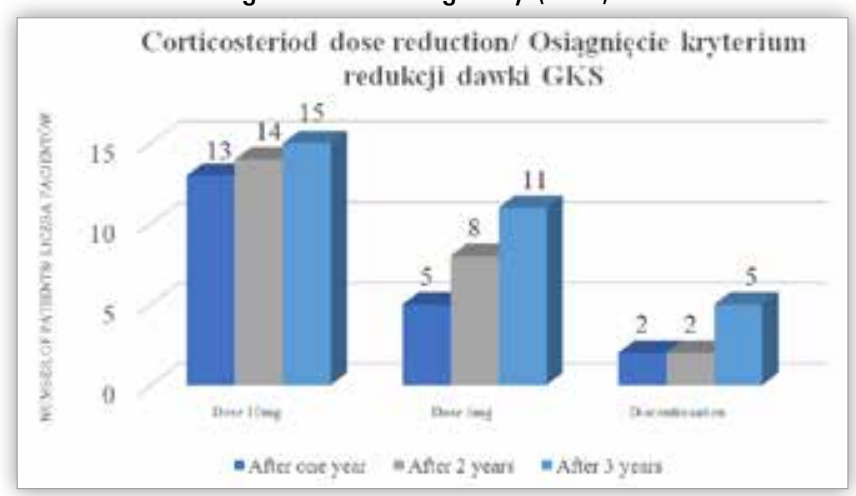

Fig. 1. Prednisone dose reduction after one, two and three years of follow-up.

Ryc. 1. Uzyskanie redukcji dawki prednizonu po roku, dwóch i trzech latach obserwacji.

All the patients received MMF for the first 6 months. After a year the treatment was continued in 12 patients $(63 \%)$, and after two years - in 4 patients $(21 \%)$. The average baseline dose of MMF was $1763 \mathrm{mg}$, with 16 patients (84\%) receiving $1500 \mathrm{mg}$ or $2000 \mathrm{mg}$ daily. The first dose reduction was done after the average of 4 months of treatment with 13 patients $(68 \%)$ having the dose reduced during the first 3 months of treatment. Average doses during two years of follow-up are included in Figure 2. The increase at 18 months of treatment was associated with an increased MMF dose in two out of six patients. In one patient the change of dose was connected with perioperative cataract prophylaxis and in the other - to the occurrence of an inflammatory episode.

The average duration of treatment in the study group was 30 months (from 4 to 106 months). The average duration of fol-

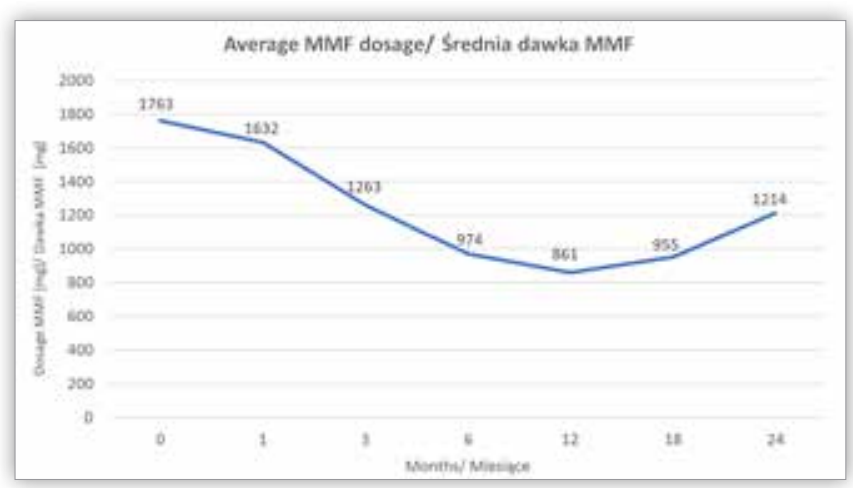

Fig. 2. Average MMF dosage.

Ryc. 2. Średnie dawki MMF.

low-up after treatment was 21 months (from 0 to 42 months). The analysis of the causes of MMF discontinuation were as follows: $59 \%$ patients achieved a therapeutic success, in $10 \%$ the therapy was ineffective, $5 \%$ of patients had adverse effects, one patient $(5 \%)$ failed to observe medical advice and made a personal decision to discontinue the drug. Four patients continued treatment with MMF at the moment of study completion.

During the treatment, inflammatory episodes occurred in eight patients (42\%). Recurrences were the most common after GC dose reduction - 4 times, 3 episodes were reported with mycophenolate mofetil dose reduction and 3 others when both MMF and GCs were reduced. The average MMF dose at which the inflammatory process recurred was $875 \mathrm{mg}$, with as many as 5 patients (62.5\%) receiving a $500 \mathrm{mg}$ dose of immunosuppressive drug at that time. However, after completing the treatment the disease recurred in 7 patients - on average after a year. Interestingly, an inflammatory episode occurred in 5 patients over a 7-month period, while no recurrences were noted over a 3-month period. A remission criterion was met in all the patients after MMF discontinuation. Detailed data are included in Table II.

Recurrence of inflammation/ Nawroty zapalenia

Data/ Dane

Patients with recurrences after dose reduction of MMF/

Liczba osób, u których wystąpił nawrót po redukcji dawki MMF

The mean dose of MMF at which the uveitis recurred/

Srednia dawka jaką podawano gdy wystąpit nawrót

$875 \mathrm{mg} / \mathrm{day}$

How many patients then received $500 \mathrm{mg} /$ day?/

llu pacjentów otrzymywało wtedy $500 \mathrm{mg} / \mathrm{dz}$ ?

Patients with recurrences after MMF discontinuation/

Liczba osób, u których wystąpił nawrót po odstawieniu MMF

The average time after which the relapse occurred [month]/

Po jakim czasie od odstawienia wystąpiła nawrót? [w miesiącach]

The number of patients whose relapse occurred after 7 months?

U ilu pacjentów nawrót wystąpił do 7. miesiąca?

Has the immunosuppressive drug been re-introduced?/

Czy lek immunosupresyjny został ponownie włączony?

Which drug was re-introduced?/ Jaki lek włączono ponownie?

MMF-2

MTX-1

Tab. II. Detailed data on recurrence of inflammation during the whole observation.

Tab. II. Szczegółowe dane dotyczące nawrotów zapalenia podczas całej obserwacji. 
The most common ophthalmological complication occurring in the study group was cataract (15 patients, $79 \%$ ), thus phacoemulsification was the dominant surgical procedure (13 surgeries). Data are included in Figures $3 a$ and $3 b$.

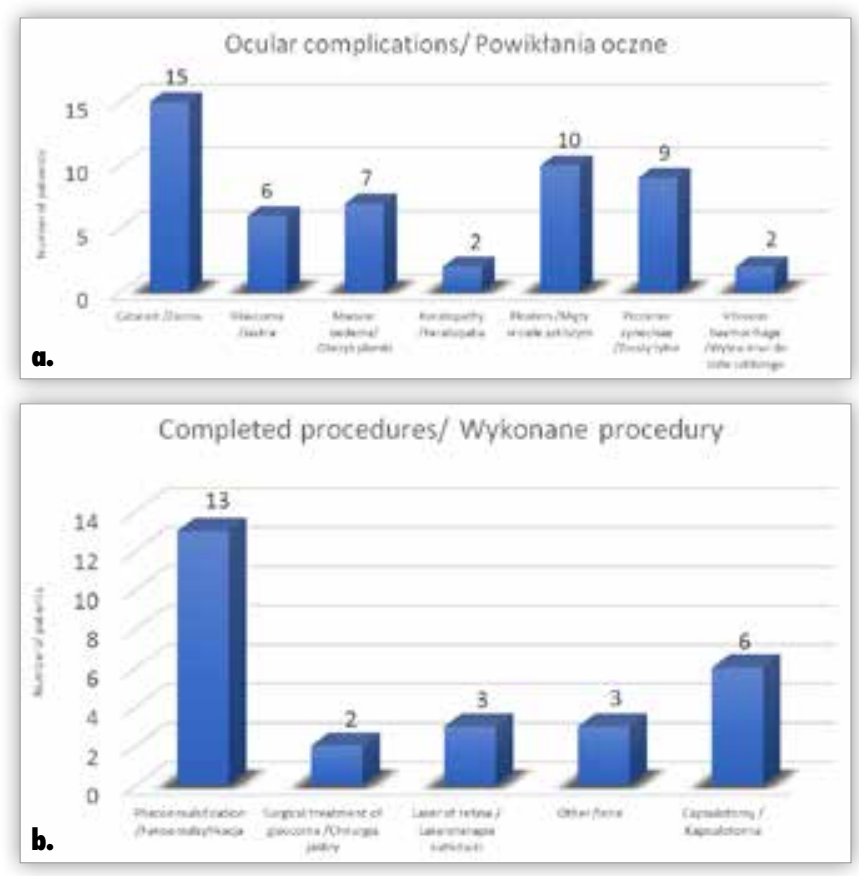

Fig 3a., 3b. Complications and procedures during the follow-up period.

Ryc. 3a., 3b. Powikłania i wykonane procedury podczas okresu obserwacji.

A long-term effect of immunosuppressive treatment was assessed on the basis of the best corrected visual acuity. The following BCVA values were compared: at the beginning of MMF treatment and at the end of follow-up. In case of bilateral disease the BCVA was analyzed in the eye with the superior visual acuity. A total of 20 out of 31 eyes (64\%) achieved vision stabilization, an improvement occurred in 8 eyes $(26 \%)$ and deterioration in $3(10 \%)$.

During mycophenolate mofetil treatment 5 patients (26\%) experienced adverse effects and 2 of them required dose reduction. Hematologic abnormalities were the most common. The severity of adverse effects necessitated drug discontinuation in one patient. She experienced hematologic complications manifesting as ecchymoses and hematomas affecting the whole skin. Despite dose reduction the patient lost her consciousness and had to be hospitalized.

\section{Discussion}

The aim of the present involved a detailed assessment of non-infectious uveitis treated with mycophenolate mofetil with the follow-up period of at least 3 years. We also assessed to what extent the therapeutic success achieved at the beginning of the treatment continued over time and how commonly the disease recurred after mycophenolate mofetil discontinuation.

The majority of published research papers concerning the use of MMF in patients with uveitis involved a short follow-up period, usually limited to a year. Few researchers concentrated on the description of changes occurring after a period of 12 months.
In the present paper therapeutic success, defined as the possibility of prednisone dose reduction to $10 \mathrm{mg}$ and also inactivity of uveitis during the $12^{\text {th }}$ month of the follow-up, was achieved by $81 \%$ of patients. Such a result is comparable with proportions obtained in other studies - from $72 \%$ (8), through $83.3 \%(9), 84.6 \%(2)$ to $86 \%$ (4) of patients. A certain aspect of GC dose reduction is worth noting. During long-term follow-up some patients achieved the aim over the first months of MMF treatment, but later, if the disease recurred, a dose increase was necessary. The present authors decided not to include graphically presented data which were prepared, because it would considerably impede the interpretation of the results.

The patients treated with mycophenolate mofetil at our clinic were initially administered a dose of $1000 \mathrm{mg}$ twice daily in most cases, which correlates with treatment regimens implemented in other centers. However, professional literature provides scarce data referring to the continuation of MMF treatment in patients with uveitis. Teoh et al. reported that in their center the initial dose amounted to $2000 \mathrm{mg}$ daily. In case of the ineffectiveness of treatment it was increased to $3000 \mathrm{mg}$ daily and reduced to $1000 \mathrm{mg}$ if good response was achieved. The authors did not specify the period during which the effectiveness was assessed (2). Chilean physicians implemented a slightly different strategy. They initiated the treatment on $500 \mathrm{mg}$ twice daily and increased it later to $2000 \mathrm{mg}$ administered in two doses. Treatment regimen was not described, but it may be indirectly inferred that high doses of MMF were administered over a long time. Two patients experienced serious complications (non-Hodgkin lymphoma and bronchioalveolar carcinoma) after a 38-month treatment with $2000 \mathrm{mg}$ of MMF and after a 36-month treatment with $1500 \mathrm{mg}$ of MMF daily. Siepmann et al. implemented a completely different regimen with the initial dose of $1000 \mathrm{mg}$ daily which was increased to $2000 \mathrm{mg}$ after a week and maintained at the same level until the end of the treatment. The average duration of MMF treatment varied depending on the segment of the uvea affected with the inflammation: anterior - 15.5 months, intermediate -20 months, posterior -15.3 and 19.5 months in panuveitis (5). MMF treatment regimen implemented at our clinic encompasses an initial dose of 1500-2000 mg daily continued for several months and then it is relatively rapidly reduced in order to achieve c.a. half of the initial dose after a 6-month therapy. After a year of treatment MMF was still administered to $63 \%$ of patients, after two years - only $31 \%$, and after 3 years - to $26 \%$ of patients.

Dochevy et al. reported MMF treatment with the follow-up period of five years, the average MMF treatment duration of 52 months (from 11 to 111 months) with only $33 \%$ of patients in whom the drug was discontinued because of achieving the pre-planned effectiveness. The authors did not include information concerning the posology. In the present study the patients were followed up for a shorter period (at least 3 years; average -51 months) and the average treatment duration was 30 months (from 4 to 106 months), but a therapeutic success was achieved in as many as $59 \%$ of patients, so MMF was discontinued. If we comprise the fact that the disease recurred in 2 patients and MMF had to be reintroduced, the percentage falls to $47 \%$. The difference may result from patient characteristics - in the study by Doycheva et al. the inflammation affected mainly the intermediate uvea $(70 \%$ of the participants) and it was demonstrated that MMF was not the most effective 
drug in this group. A study which was a part of SITE Cohort Study included 145 patients with non-infectious ocular tissue inflammation [predominantly uveitis $(63 \%)$, but also scleritis $(11 \%)$ and pemphigoid $(23 \%)]$. The patients received azathioprine as the sole immunosuppressive drug. The researchers noted that azathioprine was particularly effective in the treatment of an inflammation of the intermediate uvea. After a 6-month treatment a complete remission of the manifestations of the inflammation was achieved in $41 \%$ of patients in the whole group, and in as many as $69 \%$ in the group of intermediate uveitis (10).

In the present study 3 patients received mycophenolate mofetil as monotherapy. Two of them had no recurrences both during the treatment and the follow-up period which suggests the effectiveness of MMF monotherapy. Lau et al. reached a completely different conclusion. They assessed a long-term effect of MMF monotherapy as insufficient and reported that its combination with prednisolone and cyclosporin provided long-term remission of the inflammation (9).

SUN Working Group experts indicated that the changes in best corrected visual acuity were the most sensitive index of long-term assessment of immunosuppressive treatment in uveitis. Achieving the stabilization and even an improvement of vision in patients with uveitis is a major success, due to the fact that this disease, if left untreated, may lead to blindness. A chronic character and frequent recurrences lead to a significant reduction in visual acuity and, as a consequence, the inability to continue professional activity. Uveitis is classified as a rare disease with 38 cases per 100000 people. However, in developed countries it is the fourth most common cause of blindness in professionally active individuals. In the present study $64 \%$ of patients achieved BCVA stabilization and 26\% - BCVA improvement. The result is slightly higher than in other studies. Doycheva et al. reported a stabilization in $60 \%$ and an improvement in $22 \%$ of patients. In 2016 Rodriguez et al. reported BCVA improvement or stabilization in $75 \%$ of patients (6). As regards the results of visual acuity it needs to be emphasized that immunosuppressive treatment in uveitis is not a contraindication to cataract surgery in our department. Achieving several months of remission and the implementation of perioperative anti-inflammatory prophylaxis facilitates performing a surgery safely. Phacoemulsification was performed in 13 out of 15 patients with a diagnosis of cataract, which also contributed to good visual acuity results.

Mycophenolate mofetil is a well-tolerated immunosuppressive drug. The most commonly reported adverse effects include gastrointestinal disorders, i.e. abdominal pain, diarrhoea and vomiting. According to some authors the second most common group of complications includes fatigue, headache, general malaise, while other authors listed hematologic disorders (anemia, lymphopenia). Adverse effects were reported only in $26 \%$ of patients in this study group. Such a low percentage may result from a relatively rapid MMF dose reduction during the treatment.

Data obtained from this study confirm the long-term effectiveness of MMF in the treatment of noninfectious uveitis. A comparison with other centers treating patients with uveitis shows that treatment duration is shorter at our clinic and the high initial doses of the drug are also more rapidly reduced. However, such a treatment regimen is less demanding as regards the patient, and does not significantly affect treatment outcomes.
The duration of follow-up in our study is a major advantage of the present study. It was emphasized in the Introduction section that professional literature includes few reports assessing the disease status after 1 year of follow-up. Knowledge gained from the present study may help ophthalmologists in conducting immunosuppressive treatment in patients with non-infectious uveitis. However, the present authors are aware of limitations resulting from retrospective data analysis, as some information may have been skipped in medical records. Moreover, the number of patients with a history that was long enough might also influence the assessment of the results.

\section{References:}

1 Jabs D, Rosenbaum J, Yocum D, Holland GN, Jaffe GJ, Louie JS, et al.: Guidelines for the use of immunosuppresive drugs in patients with ocular Inflammatory Disorders: recommendations of an Expert panel. Am J of Ophthalmol. 2000; 30(4): 492-513.

2 Teoh S, Hogan A, Dick A, Lee R: Mycophenolate mofetil for the Treatment of Uveitis. Am J Ophthalmol. 2008;146(5): 752-760.

3 Larkin G, Lightman S: Mycophenolate mofetil. A useful immunosuppressive in inflammatory eye disease. Ophthalmology. 1999; 106(2): 370-374.

4 Daniel E, Thorne JE, Newcomb CW, Pujari SS, Kaçmaz RO, Levy-Clarke GA, et al.: Mycophenolate mofetil for ocular inflammation. Am J Ophthalmol. 2010;149(3): 423-432.

5 Siepmann K, Huber M, Stübiger N, Deuter C, Zierhut M: Mycophenolate mofetil is a highly effective and safe immunosuppressive agent for the treatment of uveitis: a retrospective anaIysis of 106 patients. Graefes Arch Clin Exp Ophthalmol. 2006; 244(7): 788-794.

6 Rodriguez EE, Sakata VM, Cavalcanti DC, Zaghetto JM, Olivalves $\mathrm{E}$, Hirata $\mathrm{CE}$, et al.: Mycophenolate mofetil as an immunomodulator in refractory noninfectious uveitis. Arq Bras Oftalmol. 2016; 79(6): 369-372.

7 Jabs DA, Nussenblatt RB, Rosenbaum JT: Standardization of Uveitis Nomenclature (SUN) Working Group. Standardization of uveitis nomenclature for reporting clinical data. Results of the First International Workshop. Am J Ophthalmol. 2005;140(3): 509-516.

8 Doycheva D, Zierhut M, Blumenstock G, Stuebiger N, Deuter C: Long-term results of therapy with mycophenolate mofetil in chronic non-infectious uveitis. Graefes Arch Clin Exp Ophthalmol. 2011; 249(8): 1235-1243.

9 Lau CH, Comer M, Lightman S: Long-term efficacy of mycophenolate mofetil in the control of severe intraocular inflammation. Clin Exp Ophthalmol. 2003; 31(6): 487-491.

10 Pasadhika S, Kempen J, Suhler E: Azathioprine for Ocular Inflammatory Diseases. Am J Ophthalmol. 2009; 148: 500-509.

The paper was originally received 25.10 .2018 (KO-00186-2018)/ Praca wpłynęła do Redakcji 25.10.2018 r. (KO-00186-2018) Accepted for publication 31.03.2019/ Zakwalifikowano do druku 31.03.2019 r.

Reprint requests to (Adres do korespondencji): Maja Waszczyk-Łączak, MD Independent Public University Ophthalmic Hospital, Warsaw, Poland 03-709 Warsaw, Sierakowskiego 13 Str. e-mail: majawaszczyk.laczak@gmail.com 